\title{
The Review on the Science Process Skills and the Levels to Create a Graphic: The Sample on Preservice Science Teachers*
}

\author{
Sibel DEMİR KAÇAN ${ }^{* *} \quad$ Nisa YENİKALAYCI ${ }^{* * *}$ \\ Dilek ÇELİKLER ${ }^{* * * *}$
}

\begin{abstract}
In science education, drawing tables and graphics is a part of science process skills, and preservice teachers are expected to have these skills. The aim of this study is to examine the science process skills and create a graphic levels of preservice science teachers based on a given problem scenario. In the research, the survey method has been used. The research has been conducted with 87 preservice teachers in total who receive their education at the third grade in The Department of Science Education in a state university in Blacksea region. The worksheet which has been developed by the expert researchers in their field has been used in order to collect the data. 17 items and 3 aspects have been used in order that the data on this activity worksheet has been evaluated. The exact statements which include the scientific accuracy have been encoded as sufficient, the partly scientific accuracy have been encoded as partially sufficient, and the incorrect statements and the empty answers have been encoded as insufficient. According to the frequency distribution table which has been made as a result of the data, it has been determined that the preservice teachers are insufficient on the subjects of being able to show the data of variables in the scenario on the ready figures, to position the variables correctly onto the axes. According to the results obtained from the research, it is thought that other studies can be conducted on the subjects that the preservice teachers are partially sufficient and insufficient.
\end{abstract}

Keywords: Science process skills, science education, create a graphic, preservice teachers, problem scenario

\footnotetext{
* This study was presented as an oral presentation at the 27 th International Conference on Educational Sciences (ICES UEBK) held in Antalya between 18-22 April 2018.

** Orcid ID: https://orcid.org/0000-0003-3577-3399, Dr., Ondokuz Mayıs University, Department of Science Education, Turkey, sibelfe@hotmail.com; sibel.demir@omu.edu.tr

*** Orcid ID: https://orcid.org/0000-0002-5676-1488, Ress. Assist., Ondokuz Mayıs University, Department of Science Education, Turkey, nisa.yenikalayci@omu.edu.tr

**** Orcid ID: https://orcid.org/0000-0002-9945-7195, Assoc. Prof. Dr., Ondokuz Mayıs University, Department of Science Education, Turkey, dilekc@omu.edu.tr
} 


\section{INTRODUCTION}

Many teaching contents such as concept cartoons, concept maps, problem-based learning, project-based learning, brainstorming, puzzle and puzzle creation, open-ended experiments, story writing, role-playing, creative drama, asking questions and scientific discussions can be provided in research and inquiry-based learning philosophy, and these kinds of learning experiences can have significant effects on science process skills (Demir, 2014). Inquiry positively affects students' academic success, problem-solving skills, ability to organize and reflect learning and increases motivation (Medrano, 2012). According to Werner (2007), a research-based learning approach consists of case study activities, social activities, invention-based, project-based studies and problem-solving studies. Observing and improving science process skills, especially with problem scenarios, is a very effective method.

Considering the development of science process skills with inquiry-based learning, the interaction between them is quite effective in science education (Şahin and Benzer, 2012). As a matter of fact, while Demir (2014) revealed in her study that research and inquiry-based learning have a positive effect on science process skills, Anagün and Yaşar (2009) concluded that the application of the constructivist approach based on the $5 \mathrm{E}$ model is effective on the development of science process skills of fifth-grade students. Similarly, Şensoy and Yıldırım (2017) found that the inquiry-based learning approach has a positive effect on students' science process skill levels.

Ewers (2001) defines science process skills as observing, classifying, making inferences, predicting, measuring and communicating and states that these skills are the basis for developing scientific knowledge, but besides this, many science lessons do not include the process of how knowledge is developed. Appropriate teaching methods should be used to ensure that students have a positive attitude towards science and improve their science process skills (Başdaş, 2007). Ongowo and Indoshi (2013) stated that science teachers should encourage the development of science process skills as these practices lead students to investigate important issues in their environment. Tan and Temiz (2003) in their research emphasized the importance of science process skills in science teaching with the titles of problem-solving, contribution to mental development, persistence in learning, contribution to scientific literacy, child-scientist similarity and laboratory approach.

Science process skill is an approach that enables the organization of skills suitable for different science disciplines (Karamustafaoğlu and Yaman, 2006). Actually, science process skills can be defined as the process of recognizing the science that is in life. Based on this definition, the development of science process skill requires the habit of looking at events from different perspectives.

In her study, Kemiksiz (2016) reached the conclusion that scenario-based learning provides permanence on success and attitude towards science course. In addition, Sezgin Selçuk (2015), as a result of her research conducted with science teachers, stated that the scenario is effective and useful and can be used during in-service teacher 
training. As can be seen from all these studies, problem scenarios constitute a very effective environment for inquiry-based learning. With problem scenarios, students try to find a solution to the problem in their mind and try to test the solutions by experimenting or generating ideas. Thus, they can experience the process of obtaining a scientific solution. One of the most important elements in raising individuals who can produce independent ideas, make observations, be creative, problem-solving, researcher and make interpretations is seen as experimenting especially in science lessons (Yıldırım and Türker Altan, 2017). As a matter of fact, Aydoğdu (2009) in his study which aims to examine the effects of research-based and open-ended experiment techniques used in science and technology lessons on students' science process skills, views on the nature of science and learning approaches stated that these variables affect each other.

Drawing tables and graphics in science teaching is a part of science process skills, and preservice teachers are expected to have these skills. In this context, it is thought that the use of two-dimensional tools such as tables, graphs and figures are effective tools in expressing the science process skills based on the scenario. A table or graph can sometimes summarize a very long paragraph nicely and help students learn concretely with the visual aids used. As a matter of fact, during the processing and interpretation of the data, the students draw a graph on the vertical and horizontal axis of the data obtained from the experiment, try to determine how the independent variable affects the dependent variable by interpreting the graph (Küçüközer, 2017). In this respect, according to Talaslıoğlu and Şahin (2018), graphs, which are sufficiently included in the science education programme and have an effect on the development of students' science process skills, appear as important educational tools that help concretize the data. Creating graphs and interpreting the existing graphs can provide a very effective learning process in science process skills, especially in terms of developing the analysis step. At this point, the individual feels the need to evaluate his existing knowledge and enters into structuring the knowledge as a scientific method in his mind.

As can be seen from all these literature reviews, problem scenarios, science process skills and creating graphs seem to be important elements that complement each other. Based on this point, it is thought that the development of science process skills and graph creation skills are important for forming problem-based learning and inquirybased learning environments.

In this context, the aim of the study is to examine the science process skills and graph creating levels of preservice science teachers based on a given problem scenario.

\section{METHOD}

\section{Research Model}

The research is a survey study, which aim to collect data to determine specific characteristics of a group are called survey studies (Büyüköztürk, Kılıç Çakmak, Akgün, Karadeniz, \& Demirel, 2008). Descriptive research is often used as a method to obtain 
summary information about different phenomena and events that we want to study (Büyüköztürk et al., 2008).

\section{Resarch Group}

The research has been conducted with 87 preservice teachers in total who receive their education at the third grade in The Department of Science Education in a state university in Blacksea region. In the research, the convenience sampling method was selected with respect to easy access to sampling and implementation.

\section{Collection Data Tools}

The worksheet which has been developed by the expert researchers in their field has been used in order to collect the data. In addition, preservice teachers applied the semiopen-ended experiment activity developed by the researchers as well as the activity sheet. The preservice teachers were taken to the laboratory for implementation in rotation, and the activity lasted approximately 2 lesson hours for each group.

The scenario given to preservice science teachers through the activity sheet in the study is as follows:

"One day, the teacher asks a question to three hardworking friends named Ayșe, Mehmet and Umay and says that he will award whoever answers the question correctly. The question is as follows: "Let's put a $120 \mathrm{~cm}$ long rope through a cylinder with both ends open and tie a $20 \mathrm{~g}$ mass to the end of the rope on the side that will make a circular motion. Then, let's tie a $100 \mathrm{~g}$ mass to the other end of the rope in the vertical direction, put a mark on the rope with a felt-tip pen every $10 \mathrm{~cm}$. Then, taking these points as a reference, let's turn them over our head to form circles with $10 \mathrm{~cm}, 30 \mathrm{~cm}$ and $50 \mathrm{~cm}$ radius. In which mechanism do you think the time for the mass to reach the same position will be the shortest?" The teacher gives the students 3 minutes to think and asks them to show their answers on a piece of paper at the same time. The answers are quite different from each other..."

The predictions of the three friends are given in Figure 1.

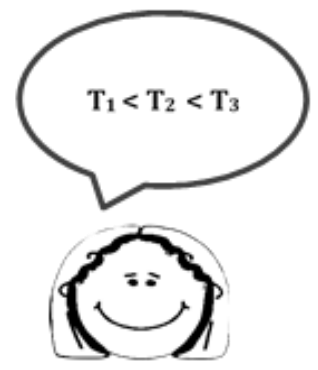

Ayşe (...)

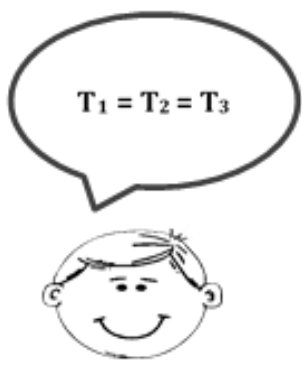

Mehmet (...)

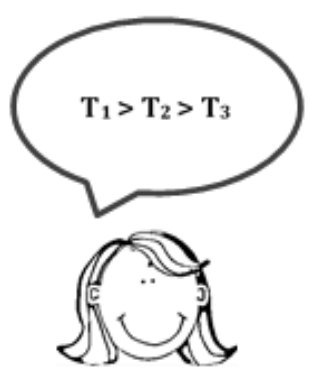

Umay (...)

Figure 1. Predictions of the three friends 
Semi-open-ended experiment process:

"As a result of these different answers, the teacher asks the students to carry out this experiment. The students start measuring the times with a stopwatch by obtaining the necessary materials and setting up the mechanism. Realizing that one full turn of the mass that moves in a circular motion is very short and that it will be very difficult to measure with a stopwatch, Mehmet suggests to his friends to measure the time that passes for 10 complete turns of the mass and from there to switch to period measurement. Umay, who thinks that this idea will be good, states that they cannot get accurate results with a single measurement and emphasizes the necessity of repeating the same operations 5 times for each radius distance. Ayșe also agrees with Mehmet and Umay friends, and they start to obtain the data together."

$\checkmark$ First; the times elapsed for 10 complete turns of a $10 \mathrm{~cm}$ radius circle are $2.40 \mathrm{~s} ; 2.42$ s; $2.38 \mathrm{~s} ; 2.43 \mathrm{~s} ; 2.47 \mathrm{~s}$

$\checkmark$ Later; the times elapsed for 10 complete turns of a $30 \mathrm{~cm}$ circle are $2.85 \mathrm{~s} ; 2.82 \mathrm{~s}$; $2.96 \mathrm{~s} ; 2.79 \mathrm{~s} ; 2.93 \mathrm{~s}$ and

$\checkmark$ Then; the times elapsed for 10 complete turns of a $50 \mathrm{~cm}$ radius circle are $3.11 \mathrm{~s}$; 3.14 s; 3.17 s; 3.14 s; 3,20 s.

The ready-made shapes are given in Figure 2.
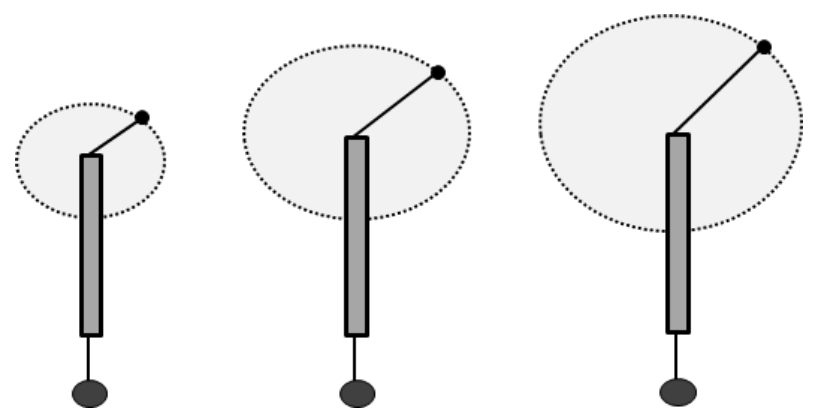

Figure 2. Ready-made shapes

\section{Analysis of Data}

The 17 evaluation criteria used for the evaluation of the data in the activity sheet were created from the pool prepared by science expert researchers by creating various codes. For the analysis of these evaluation criteria, 3 dimensions were determined as Likert type, which includes sufficient, partially sufficient and insufficient options. Validity was achieved by comparing the evaluation criteria and dimensions of the two researchers. Descriptive analysis was used as a method of analyzing qualitative data in the study. Yıldırım and Şimşek (2006) define descriptive analysis as summarizing and interpreting data according to predetermined themes and data are placed according to the thematic framework created based on the existing dimensions. Here, the findings are defined and interpreted by providing direct quotations where necessary. Indeed, in research, the 
exact statements which include the scientific accuracy have been encoded as sufficient, the partly scientific accuracy (if the number of correct numbers are more than the number of errors) have been encoded as partially sufficient, and the incorrect statements and the empty answers have been encoded as insufficient.

In order for a research to be considered as scientifically accurate, it should also be examined by other researchers (Ylldırım and Şimşek, 2006; Yıldırım, 2010). Therefore, the percentage of agreement of two researchers was checked with the formula [Agreement/(Disagreement + Agreement) x 100] (Miles and Huberman, 1994) and this value was calculated as $90 \%$.

\section{FINDINGS}

The findings regarding the preservice teachers' skills of analyzing the problem scenario before the graph creation process have been analyzed and presented. The evaluation of the preservice teachers' ability to make predictions is given in Table 1.

Table 1

Evaluating the ability to make predictions

\begin{tabular}{lccc}
\hline Evaluation Criteria & Sufficient & $\begin{array}{c}\text { Partially } \\
\text { Sufficient }\end{array}$ & Insufficient \\
\hline $\begin{array}{l}\text { Being able to make a prediction based } \\
\text { on the scenario and explain the reason }\end{array}$ & 34 & 42 & 11 \\
\hline
\end{tabular}

When Table 1 is examined, it is seen that the preservice teachers' ability to make a prediction based on the scenario and explain the reason is partially sufficient $(f=42)$. The evaluation of preservice teachers' ability to record data on the shape is given in Table 2 .

Table 2

Evaluation of the ability to record data on the shape

Evaluation Criteria

Sufficient

Partially

Sufficient

Insufficient

Being able to show the data of the

variables in the scenario on the given

20

32

35

shapes 
When Table 2 is examined, it is seen that preservice teachers' ability to show the data of the variables in the scenario on the given shapes is insufficient $(\mathrm{f}=35)$. The evaluation of preservice teachers' ability to determine hypothesis and variables is given in Table 3.

Table 3

Evaluation of the ability to identify hypotheses and variables

\begin{tabular}{|c|c|c|c|}
\hline Evaluation Criteria & Sufficient & $\begin{array}{l}\text { Partially } \\
\text { Sufficient }\end{array}$ & Insufficient \\
\hline $\begin{array}{l}\text { Being able to determine an appropriate } \\
\text { hypothesis for the scenario }\end{array}$ & 58 & 24 & 5 \\
\hline $\begin{array}{l}\text { Being able to express the independent } \\
\text { variable }\end{array}$ & 38 & 20 & 29 \\
\hline $\begin{array}{l}\text { Being able to express the dependent } \\
\text { variable }\end{array}$ & 37 & 16 & 34 \\
\hline $\begin{array}{l}\text { Being able to express the controlled } \\
\text { (constant) variables }\end{array}$ & - & 75 & 12 \\
\hline
\end{tabular}

When Table 3 is examined, it is seen that preservice teachers' ability to determine an appropriate hypothesis for the scenario is sufficient $(\mathrm{f}=58)$, ability to express the independent variable is sufficient $(\mathrm{f}=38)$, ability to express the dependent variable is sufficient ( $\mathrm{f}=37$ ) and ability to express the controlled (constant) variables is partially sufficient for $(\mathrm{f}=75)$. The evaluation of preservice teachers' ability to create a table is given in Table 4.

Table 4

Evaluation of the ability to create a table

$\begin{array}{lcc}\text { Evaluation Criteria } & \text { Sufficient } & \begin{array}{c}\text { Partially } \\ \text { Sufficient }\end{array}\end{array}$ Insufficient

Being able to create an appropriate table based on the scenario 
scenario and record in the table

Being able to express the units and symbols belonging to the variables correctly for the

table

When Table 4 is examined, preservice teachers' ability to create an appropriate table based on the scenario is sufficient $(\mathrm{f}=69)$, ability to organize the data in the scenario and record in the table is partially sufficient $(\mathrm{f}=46)$ and ability to express the units and symbols belonging to the variables correctly for the table is partially sufficient $(f=39)$. An example table created by preservice teachers is given in Figure 3.

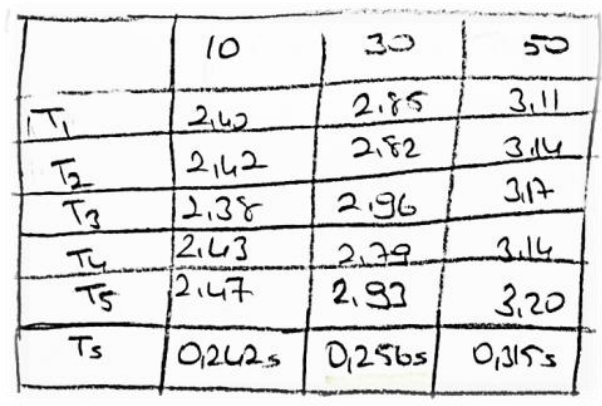

Figure 3. Example table

When Figure 3 is examined, it is seen that the preservice teachers used the period (T) symbol for the time elapsed for (PT63w) 10 complete turns, but they did not express the second (s) as the unit and did not express the radius variable on the table with a symbol (r) and unit ( $\mathrm{cm}$ or $\mathrm{m}$ ). The evaluation of the graph drawing skills of the preservice teachers is given in Table 5 .

Table 5

Evaluation of the ability to create a table

\begin{tabular}{lccc}
\hline Evaluation Criteria & Sufficient & $\begin{array}{c}\text { Partially } \\
\text { Sufficient }\end{array}$ & Insufficient
\end{tabular}

Being able to create an appropriate graph based on the data in the table 
Being able to position variables accurately on axes

Being able to express the units and symbols belonging to the variables correctly for the graph

Being able to place the data proportionally to the axes

Being able to place the data correctly in the table on graph paper

Being able to show the point of the data by drawing a small circle around the specified

Being able to draw an appropriate line/curve covering the determined points

Being able to explain the similarities and differences between initial prediction and observation results

When Table 5 is examined, it is seen that preservice teachers' ability to create an appropriate graph based on the data in the table is sufficient $(\mathrm{f}=84)$, ability to position variables accurately on axes is insufficient $(\mathrm{f}=43$ ), ability to express the units and symbols belonging to the variables correctly for the graph is partially sufficient $(\mathrm{f}=56)$, ability to place the data proportionally to the axes is sufficient $(\mathrm{f}=71)$, ability to place the data correctly in the table on graph paper is partially sufficient $(\mathrm{f}=73)$, ability to show the point of the data by drawing a small circle around the specified point is partially sufficient $(\mathrm{f}=66)$, ability to draw an appropriate line/curve covering the determined points is sufficient $(\mathrm{f}=79)$ and ability to explain the similarities and differences between initial prediction and observation results is partially sufficient $(\mathrm{f}=35)$.

An example graphic created by preservice teachers is given in Figure 4. 


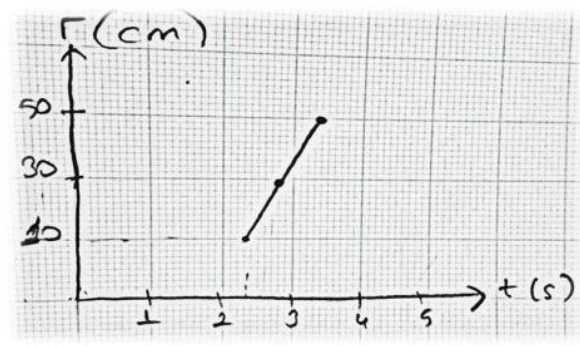

Figure 4. Example graph

When Figure 3 is examined, it is seen that the preservice teachers (PT40w) could not place dependent (period-T) and independent (radius-r) variables on the correct axes according to the graph they drew and instead of period $\mathrm{T}(\mathrm{s})$, used $\mathrm{t}(\mathrm{s})$ for the time value obtained for each measurement in the drawing.

\section{CONCLUSION, DISCUSSION AND SUGGESTIONS}

It has been determined that there are points where the science process skills of preservice science teachers for a given problem scenario are insufficient, partially sufficient and sufficient regarding recording data, using the data and creating a model which are among the science process skills and creating tables and graphs which covers data interpretation steps. The process of extracting and determining data obtained from a scenario and transforming these data into graphs seems to be significantly related to science process skills. The ability to identify and extract data from an existing situation, create graphs from these data and interpret the graph can be expressed as a very important situation in terms of science literacy. As a matter of fact, according to Yeh and McTigue (2009), it is emphasized that visual literacy such as table and graphic reading should be taught especially at an early age in order to raise individuals who can make decisions in many areas. The most important person who can realize this situation in the individual is seen as the science teachers.

When the results obtained from the study are examined, although the preservice science teachers have at a sufficient level of determining an appropriate hypothesis belonging to the scenario, expressing the dependent and independent variables, it is important to state that they have partially sufficient level of making predictions based on the scenario and explaining the reason, and expressing the controlled (constant) variables and they have an insufficient level of showing the data of the variables in the scenario on the given figures and positioning the variables correctly on the axes. At this point, it is seen that preservice science teachers need a little more experience, especially in determining variables.

While it was determined that preservice science teachers could create a table from the scenario and an appropriate graph based on the data obtained from the table, the fact 
that they have an insufficient level of showing the data belonging to the variables included in the scenario on the given figures indicates that this skill has not yet fully developed in preservice teachers regarding the ability to extract and interpret the data from the scenario. In the study conducted by Kozcu Çakır and Sarıkaya (2018), it was determined that the preservice teachers have good skills in such dimensions as constructing and interpreting hypotheses, determining variables, reading and interpreting the graph, designing an experiment and interpreting the results and recording the data of the experiment with respect to their integrated process skills while it was observed that they had difficulties in defining and determining dependent, independent and controlled variables and in identifying and understanding science process skills. As a matter of fact, when another study on science process skills is examined, it is seen that students have deficiencies in interpreting data and graphics (Bowen \& Roth, 2005). Accordingly, Talaslıoglu and Şahin (2018) emphasized that sufficient importance should be given and supported to the graphic reading skill, which is included in international exams, in order to create a difference in the perception of the individual.

In the study conducted by Abdi (2014), it was determined that the inquiry-based learning method had an effect on the academic achievement of the students in the science course. According to Kaptan and Korkmaz (1999), science process skill develops more than organizing observable information and using these skills in daily life and having a more positive attitude towards science. As a result of the research conducted by Ünaldı (2012), it was determined that the science education practice based on science process skills has positively changed students' attitudes towards science and technology lesson and their science process skills. In addition, Meador (2003) emphasized that thinking and discussing like a scientist are necessary for science process skills. Based on all these literature and results, it is thought that it is necessary to focus more effectively on these deficiencies existing in the teaching process in order for our students to reach a point where they can compete at an international level and develop their skills. It is thought that the experimental activities associated with the problem scenarios and including the steps such as creating tables, graphs and figures are essential for the students to develop their science process skills and to construct inquiry-based learning more effectively.

In this context, it is thought that such practices should be adapted to different subjects, contents and acquisitions, and similar situations should be presented more to the preservice teachers. 


\section{References}

Abdi, A. (2014). The effect of inquiry-based learning method on students' academic achievement in science course. Universal Journal of Educational Research, 2(1), 37-41.

Anagün, Ş. S., \& Yaşar, Ş. (2009). İlköğretim beşinci sınıf fen ve teknoloji dersinde bilimsel süreç becerilerinin geliştirilmesi [Developing scientific process skills at Science and Technology course in fifth grade students]. Ilköğretim Online, 8(3), 843-865.

Aydoğdu, B. (2009). Fen ve teknoloji dersinde kullanılan farklı deney tekniklerinin öğrencilerin bilimsel süreç becerilerine, bilimin doğasına yönelik görüşlerine, laboratuvara yönelik tutumlarına ve öğrenme yaklaşımlarına etkileri [The effects of different laboratory techniques on students' science process skills, views towards nature of science, attitudes towards laboratory and learning approaches in science and technology course]. Unpublished Doctoral Dissertation, Dokuz Eylül University, İzmir.

Başdaş, E. (2007). İlköğretim fen eğitiminde, basit malzemelerle yapılan fen aktivitelerinin bilimsel süreç becerilerine, akademik başarlya ve motivasyona etkisi [The effect of hands-on science learning method in the education of science in primary school on the science process skills, academic achievement and motivation]. Unpublished Masters' Thesis, Celal Bayar University, Manisa.

Bowen, G. M., \& Roth, W. M. (2005). Data and graph interpretation practices among preservice science teachers. Journal of Research in Science Teaching, 42(10), 1063-1088.

Büyüköztürk, Ş., Kılıç Çakmak, E., Akgün, Ö. E., Karadeniz, Ş. ve Demirel, F. (2008). Bilimsel araştırma yöntemleri [Scientific research methods]. Ankara: Pegem Akademi.

Demir, S. (2014). Bilimsel tartışma ve araştırmaya dayalı tasarlanan laboratuvar programının, Fen Bilgisi ögretmen adaylarının bilimsel yaratıcllklarına etkisi [The effect of scientific argumentation and inquiry-based laboratory program on prospective science teachers' scientific creativity]. Unpublished Doctoral Dissertation, Marmara, İstanbul.

Ewers, T. G. (2001). Teacher-directed versus learning cycles methods: Effects on science process skills mastery and teacher efficacy among elementary education students. Doctoral Thesis, University of Idaho, Moscow.

Kaptan, F., \& Korkmaz, H. (1999). Illköğretimde etkili öğretme ve öğrenme öğretmen el kitabı [Effective teaching and learning teacher's handbook in primary education.]. İlköğretimde Fen Bilgisi Öğretimi, Modül 7.

Karamustafaoğlu, O., \& Yaman, S. (2006). Fen eğitiminde özel öğretim yöntemleri I-II [Special teaching methods in science education I-II]. Ankara: Anı.

Kemiksiz, C. (2016). 6. sinıf fen bilimleri dersinde senaryo temelli öğrenme yönteminin akademik başarı tutum ve kalıcllğa etkisi [Effects of using scenario-based learning method in 6th grade science classes on academic achievement and permanence]. Unpublished Masters' Thesis, Abant İzzet Baysal University, Bolu.

Kozcu Çakır, N., \& Sarıkaya, M. (2018). Fen Bilgisi öğretmen adaylarının bilimsel süreç becerilerinin değerlendirilmesi [Evaluation of scince process skills of pre-service science teachers]. Turkish Studies, 13(4), 859-884.

Küçüközer, H. (2017). Fizik öğretiminde problem tabanlı öğrenme ve problem çözme stratejisi [Problembased learning and problem solving strategy in physics teaching]. A. İ. Şen and A. R. Akdeniz (Eds.), Fizik ögretimi, kuramsal bilgiler ve örnek etkinlik uygulamaları [Physics education, theoretical information and sample applications] in (pp. 251-283), (1st ed.), Ankara: Pegem Akademi.

Meador, K. S. (2003). Thinking creatively about science suggestions for primary teachers. Gifted Child Today, 26(25), 25-29.

Medrano, J. (2012). The effect of cognitively guided instruction on primary students' math achievement, problem solving abilities and teacher questioning. Doctoral Thesis, Arizona State University, USA.

Miles, M. B., \& Huberman, A. M. (1994). Qualitative data analysis. (2nd ed.), Thousand Oaks: Sage. 
Ongowo, R. O., \& Indoshi, F. C. (2013). Science process skills in the Kenya certificate of secondary education biology practical examinations. Creative Education, 4(11), 713-717.

Sezgin Selçuk, G. (2015). A problem-based learning scenario that can be used in science teacher education. Asia-Pacific Forum on Science Learning and Teaching, 16(2), 1-26.

Şahin, F., \& Benzer, E. (2012). Dört soru stratejisiyle geliştirilen proje uygulamalarının bilimsel süreç becerilerine etkisi [The effect of the project practices improved with four question strategy to science process skills]. Necatibey Eğitim Fakültesi Elektronik Fen ve Matematik Eğitimi Dergisi (EFMED), 6(1), 306-337.

Şensoy, Ö., \& Yıldırım, H. İ. (2017). Araştırma soruşturma tabanlı öğrenme yaklaşımının yaratıcı düşünme ve bilimsel süreç becerilerine etkisi [Effects of Inquiry Based Learning Approach on Creative Thinking and Scientific Process Skills]. Cumhuriyet International Journal of Education (CIJE), 6(1), 34-46.

Talaslığlu, S. S., \& Şahin, F. (2018). Ortaokul 7. sınıf öğrencilerinin grafik okuryazarlığı etkinlikleri ile karar verme becerileri ve kavram öğrenmeleri arasındaki ilişkinin incelenmesi guage [Research on correlation and relationship between graphic literacy activities, decision making abilities and concept learning of third grade students]. Journal of Human Sciences, 15(1), 62-76.

Tan, M., \& Temiz, B. K. (2003). Fen öğretiminde bilimsel süreç becerilerinin yeri ve önemi [The importance and role of the science process skills in science teaching]. Pamukkale Üniversitesi Eğitim Fakültesi Dergisi, 1(13), 89-101.

Ünaldı, Ö. (2012). Bilimsel süreç becerilerine dayalı fen eğitiminin öğrencilerin fen ve teknoloji dersine ilişkin tutumlarına ve bilimsel süreç becerilerine etkisi [Effect of the scientific process skills -based science education on students' science attitudes and scientific process skils]. Unpublished Masters' Thesis, Ankara University, Ankara.

Werner, R. J. (2007). Inquiry-based learning at Minnesota's University of St. Thomas. International Journal of Learning, 14(1), 51-56.

Yeh, Y. F. Y., \& McTigue, E. M. (2009). The frequency, variation, and function of graphical representations. School Science and Mathematics, 109(8), 435-449.

Yıldırım, A., \& Şimşek, H. (2006). Sosyal bilimlerde nitel araştırma yöntemleri [Qualitative research methods in the social sciences]. Ankara: Seçkin.

Yıldırım, K. (2010). Nitel araştırmalarda niteliği artırma [Increasing the quality in qualitative research]. Ilköğretim Online, 9(1), 79-92.

Yıldırım, M., \& Türker Altan, S. (2017). Araştırma ve sorgulamaya dayalı öğrenme yaklaşımının ilkokul öğrencilerinin bilimsel süreç becerilerine etkisi [Effect of inquiry-based learning approach on primary school pupils' science process skills]. Mustafa Kemal Üniversitesi Sosyal Bilimler Enstitüsü Dergisi, 14(38), 71-89. 
In the writing process of the study titled "The Review on the Science Process Skills and the Levels to Create a Graphic: The Sample on Preservice Science Teachers", the rules of scientific, ethical and citation were followed; it was undertaken by the authors of this study that no falsification was made on the collected data. "Sakarya University Journal of Education Journal and Editor" had no responsibility for all ethical violations to be encountered, and all responsibility belongs to the authors and that the study was not submitted for evaluation to any other academic publishing environment. 


\title{
Bilimsel Süreç Becerileri ve Grafik Oluşturabilme Düzeylerinin İncelenmesi: Fen Bilgisi Öğretmen Adayları Örneği ${ }^{*}$
}

\author{
Sibel DEMİR KAÇAN ${ }^{* *} \quad$ Nisa YENİKALAYCI*** \\ Dilek ÇELİKLER ${ }^{* * * *}$
}

\begin{abstract}
Öz. Fen öğretiminde tablo ve grafik çizme bilimsel süreç becerilerinin bir parçası olup, öğretmen adaylarının bu becerilere sahip olması beklenmektedir. $\mathrm{Bu}$ araştırmanın amacını Fen Bilgisi öğretmen adaylarının verilen bir problem senaryosundan yola çıkarak bilimsel süreç becerilerinin ve grafik oluşturabilme düzeylerinin incelenmesi oluşturmaktadır. Araştırmada, tarama modeli kullanılmıștır. Araştırma, Karadeniz bölgesinde bulunan bir devlet üniversitesinin Fen Bilgisi Öğretmenliği programı 3. sınıfında öğrenim görmekte olan toplam 87 öğretmen adayı ile yürütülmüştür. Verilerin toplanması amacıyla alanında uzman araştırmacılar tarafından geliştirilen etkinlik kâğıdı kullanılmıştır. Bu etkinlik kağıdında yer alan verilerin değerlendirilmesi için 17 madde ve 3 boyut belirlenmiştir. Bilimsel doğruluk içeren tam ifadeler yeterli, kısmen bilimsel doğruluk içeren ifadeler kısmen yeterli ve hatalı ifadelerin fazla olması ve boş yanıtlar yetersiz olarak kodlanmıştır. Verilerin analizi sonucunda oluşturulan frekans dağılımı tablosuna göre öğretmen adaylarının; senaryo içerisinde geçen değişkenlere ait verileri hazır olarak verilen şekiller üzerinde gösterebilme, değişkenleri eksenler üzerinde doğru konumlandırabilme konularında yetersiz oldukları belirlenmiştir. Araştırmadan elde edilen sonuçlara göre öğretmen adaylarının kısmen yeterli ve yetersiz oldukları konulara ilişkin başka çalışmaların da yapılabileceği düşünülmektedir.
\end{abstract}

Anahtar Kelimeler: Bilimsel süreç becerileri, fen eğitimi, grafik oluşturma, öğretmen adayl, problem senaryosu

\footnotetext{
* Bu çalışma, 18-22 Nisan 2018 tarihleri arasında Antalya'da gerçekleştirilen 27. Uluslararası Eğitim Bilimleri Kongresi'nde (ICES UEBK) sözlü bildiri olarak sunulmuștur.

** Orcid ID: https://orcid.org/0000-0003-3577-3399, Dr., Ondokuz Mayıs Üniversitesi, Fen Bilgisi Eğitimi, Türkiye, sibelfe@hotmail.com ; sibel.demir@omu.edu.tr

*** Orcid ID: https://orcid.org/0000-0002-5676-1488, Arş. Gör., Ondokuz Mayıs Üniversitesi, Fen Bilgisi Eğitimi, Türkiye, nisa.yenikalayci@omu.edu.tr

**** Orcid ID: https://orcid.org/0000-0002-9945-7195, Doç. Dr., Ondokuz Mayıs Üniversitesi, Fen Bilgisi Eğitimi, Türkiye, dilekc@omu.edu.tr
}

Demir Kaçan, S., Yenikalaycı, N., \& Celikler, D. (2020). The Review on the Science Process Skills and the Levels to Create a Graphic: The Sample on Preservice Science Teachers, Sakarya University Journal of Education, 10(3), 445458. doi: https://doi.org/10.19126/suje.631918 


\section{GİRIŞ}

Araştırma ve sorgulamaya dayalı öğrenme felsefesinde kavram karikatürleri, kavram haritaları, probleme dayalı öğrenme, projeye dayalı öğrenme, beyin firtınası, bulmaca ve puzzle oluşturma, açık uçlu deneyler, hikâye yazma, rol oynama, yaratıcı drama, soru sorma ve bilimsel tartışma gibi birçok öğretim içeriği sunulabilmekte ve bu tür öğrenme yaşantıları bilimsel süreç becerileri üzerinde oldukça önemli etkiler oluşturabilmektedir (Demir, 2014). Sorgulama, öğrencinin akademik başarısını, problem çözme becerisini, öğrenmeyi düzenleme ve yansıtma becerisini olumlu yönde etkilemekte ve motivasyonu arttırmaktadır (Medrano, 2012). Werner'a (2007) göre araştırmaya dayalı öğrenme yaklaşımı; vaka çalışması etkinlikleri, toplumsal içerikli etkinlikler, buluş temelli, proje tabanlı çalışmalar ve problem çözme çalışmalarından oluşmaktadır. Özellikle problem senaryoları ile bilimsel süreç becerilerini gözlemleyebilmek ve geliştirebilmek oldukça etkin bir yöntem olarak karşımıza çıkmaktadır.

Araştırma tabanlı öğrenmeyle bilimsel süreç becerilerinin geliştirilmesi göz önünde bulundurulduğunda, her ikisinin birbiriyle olan etkileşimi fen eğitiminde oldukça etkilidir (Şahin ve Benzer, 2012). Nitekim Demir (2014) yapmış olduğu çalışmada araştırma ve sorgulamaya dayalı öğrenmenin bilimsel süreç becerileri üzerinde olumlu etkisi olduğunu ortaya koyarken; Anagün ve Yaşar (2009), yapılandırmacı yaklaşımın 5E modeline dayalı olarak uygulanması ile ilköğretim beşinci sınıf öğrencilerinin bilimsel süreç becerilerinin gelişimi üzerinde etkili olduğu sonucuna ulaşmışlardır. Benzer şekilde Şensoy ve Yıldırım (2017), araştırma soruşturma tabanlı öğrenme yaklaşımının öğrencilerin bilimsel süreç beceri düzeylerine olumlu etkide bulunduğu sonucuna ulaşmışlardır.

Ewers (2001) bilimsel süreç becerilerini; gözlem yapma, sınıflandırma, çıkarımda bulunma, tahmin yapma, ölçme ve iletişim kurma olarak betimlerken; bu becerilerin bilimsel bilgiyi geliştirmek için temel oluşturduğunu ancak bunun yanı sıra, birçok fen dersinin bilginin nasıl geliştirildiği sürecini içermediğini de ifade etmektedir. Öğrencilerin bilime karşı olumlu tutum oluşturmalarını sağlamak, bilimsel süreç becerilerini geliştirmek için uygun öğretim yöntemlerinin kullanılması gerekmektedir (Başdaş, 2007). Ongowo ve Indoshi (2013) ise, Fen Bilgisi öğretmenlerinin bilimsel süreç becerileri gelişimini teşvik etmesi gerektiğini belirtirken; bu uygulamaların öğrencilerin çevrelerindeki önemli konuları araştırmalarına neden olduğunu belirtmişlerdir. Tan ve Temiz (2003) yaptıkları araştırmalarında; bilimsel süreç becerilerinin fen öğretimindeki önemini, problem çözme, zihinsel gelişime katkl, öğrenmede kalıcılık, bilimsel okuryazarlığa katkı, çocuk-bilim adamı benzerliği ve laboratuvar yaklaşımı başlıklarıyla vurgulamışlardır.

Bilimsel süreç becerileri, farklı fen disiplinlerine uygun yeteneklerin düzenlenmesini sağlayan bir yaklaşımdır (Karamustafaoğlu ve Yaman, 2006). Bilimsel süreç becerileri, aslında yaşamın içerisinde olan bilimi fark edebilme süreci olarak tanımlanabilmektedir. $\mathrm{Bu}$ tanımdan da yola çıkarak, bilimsel süreç becerisinin gelişimi, olaylara farklı pencerelerden bakabilme alışkanlığı gerektirmektedir. 
Kemiksiz (2016) yaptığı çalışmada, senaryo temelli öğrenmenin fen bilimleri ders başarısı ve tutum üzerinde kalıcılığı sağladığı sonucuna ulaşmıştır. Ayrıca Sezgin Selçuk (2015), Fen Bilgisi öğretmenleri ile yapmış olduğu araştırması sonucunda, senaryonun etkili ve faydalı olduğunu, hizmet içi öğretmen eğitimi sırasında kullanılabileceğini ifade etmiştir. Tüm bu araştırmalardan da görüleceği üzere, problem senaryoları sorgulamaya dayalı öğrenme için oldukça etkin bir ortam oluşturmaktadır. Problem senaryoları ile öğrenci zihninde, soruna ilişkin bir çözüm arama çabası içerisinde bulunmakta ve çözüm yollarını deney yaparak ya da fikir üreterek deneme sınama yoluna gitmektedir. Böylece bilimsel bir çözüm elde etme sürecini yaşayabilmektedir. Bağımsız fikir üretebilen, gözlem yapan, yaratıcı, problem çözen, araştırmacı ve yorum yapabilen bireylerin yetiştirilmesinde en önemli unsurlardan biri de özellikle fen derslerinde deney yapmak olarak görülmektedir (Yıldırım ve Türker Altan, 2017). Nitekim Aydoğdu (2009), fen ve teknoloji dersinde kullanılan araştırmaya dayalı ve açık uçlu deney tekniklerinin öğrencilerin bilimsel süreç becerilerine, bilimin doğasına yönelik görüşlerine ve öğrenme yaklaşımlarına etkilerini incelemeyi amaçladığı araştırmasında bu değişkenlerin birbirini etkilediğini ifade etmiştir.

Fen öğretiminde tablo ve grafik çizme bilimsel süreç becerilerinin bir parçası olup, öğretmen adaylarının bu becerilere sahip olması beklenmektedir. Bu kapsamda tablo, grafik, şekil gibi iki boyutlu araçların kullanımının, senaryoya dayalı bilimsel süreç becerilerini ifade etmede etkili birer araç oldukları düşünülmektedir. Bir tablo veya grafik bazen çok uzun bir paragrafı güzel bir şekilde özetleyebilmekte ve kullanılan görsellik ile öğrencilerin somut öğrenmelerine yardımcı olabilmektedir. Nitekim öğrenciler verilerin işlenmesi ve yorumlanması aşamasında, deneyden elde ettikleri verileri, düşey ve yatay eksende olmak üzere bir grafik çizerler; grafiği yorumlayarak bağımsız değişkenin bağımlı değişkeni nasıl etkilediğini belirlemeye çalışırlar (Küçüközer, 2017). Bu açıdan Talaslıoğlu ve Şahin'e (2018) göre, fen eğitim öğretim programında yeterince yer verilen ve öğrencilerin bilimsel süreç becerilerinin gelişmesinde etkisi olan grafikler, verileri somutlaştırmaya yardımcı olan önemli eğitim araçları olarak karşımıza çıkmaktadır. Grafik oluşturma ve mevcut olan grafiği yorumlama, bilimsel süreç becerilerinde özellikle analiz basamağı işlem süreçlerini geliştirme açısından oldukça etkin bir öğrenme sürecinin yaşanmasını sağlayabilmektedir. Bu noktada birey var olan bilgisini yordama ihtiyacı hissetmekte ve zihninde bilimsel süreç olarak yapılandırma içerisine girmektedir.

Tüm bu alan yazın araştırmalarından da görüldügü üzere problem senaryoları, bilimsel süreç becerileri ve grafik oluşturma birbirini tamamlayan önemli unsurlar olarak karşımıza çıkmaktadır. Bu noktadan yola çıkarak bilimsel süreç becerileri ve grafik oluşturabilme becerilerinin gelişiminin probleme dayalı öğrenme ve sorgulamaya dayalı öğrenme ortamlarının oluşturulabilmesi için önemli olduğu düşünülmektedir.

Bu kapsamda yapılan araştırmanın amacı, Fen Bilgisi öğretmen adaylarının, verilen bir problem senaryosundan yola çlkarak bilimsel süreç becerilerinin ve grafik oluşturabilme düzeylerinin incelenmesi olarak belirlenmiştir. 


\section{YÖNTEM}

\section{Araștırma Modeli}

Araştırma, bir tarama çalışması olup; bir grubun belirli özelliklerini belirlemek adına verilerin toplanmasını amaçlayan çalışmalara tarama araştırması denilmektedir (Büyüköztürk, Kılıç Çakmak, Akgün, Karadeniz ve Demirel, 2008). Betimsel araştımalar, çalışmak istenilen farklı olgu ve olaylar hakkında özet bilgi elde edebilmede genellikle başvurulan bir yöntem olarak karşımıza çıkmaktadır (Büyüköztürk ve arkadaşları, 2008).

\section{Çalışma Grubu}

Araştırma, Karadeniz bölgesinde bulunan bir devlet üniversitesinin Fen Bilgisi Eğitimi programı 3. sınıfında öğrenim görmekte olan toplam 87 öğretmen adayı ile yürütülmüştür. Araştırmada, örnekleme kolay ulaşabilme ve uygulama yapabilme bakımından uygun örnekleme yöntemi seçilmiştir.

\section{Verilerin Toplanması}

Araştırmada verilerin toplanması amacıyla araştırmayı yapan; fen eğitiminde alan uzmanı ve fen bilim uzmanı araştırmacılar tarafından geliştirilen etkinlik kâğıdı kullanılmıştır. Ayrıca etkinlik kâğıdı ile birlikte öğretmen adaylarının araştırmacılar tarafından geliştirilen yarı açık uçlu deney etkinliğini uygulamaları sağlanmıştır. Öğretmen adayları uygulama için laboratuvara dönüşümlü olarak alınmış olup her grup için etkinlik yaklaşık 2 ders saati sürmüştür.

Araștırmada etkinlik kâğıdı ile Fen Bilgisi öğretmen adaylarına verilen senaryo şu şekildedir:

“Bir gün öğretmen; Ayșe, Mehmet ve Umay isimli üç çalışkan arkadaşa şu şekilde bir soru yöneltir ve soruyu kim doğru bilirse onu ödüllendireceğini söyler. Soru şu şekildedir: "İki ucu açık bir silindir içerisinden $120 \mathrm{~cm}$ uzunluğunda bir ip geçirelim. İin dairesel hareket yapacak olan taraftaki ucuna 20 g'lık bir kütle bağlayalım. Sonra ipin düşey doğrultudaki diğer ucuna 100 g'lık kütle bağlayalım. İp üzerine her $10 \mathrm{~cm}$ 'de bir keçeli kalem ile işaret koyalım. Daha sonra bu noktaları referans alarak $10 \mathrm{~cm}, 30 \mathrm{~cm}$ ve $50 \mathrm{~cm}$ yarıçaplı daireler oluşturacak şekilde başımızın üzerinde çevirelim. Sizce hangi düzenekteki kütlenin aynı konumuna gelme süresi en kısa olur?” Öğretmen öğrencilere düşünmeleri için 3 dakika süre verir ve onlardan yanıtlarını bir kâğıda yazarak aynı anda göstermelerini ister. Gelen yanitlar birbirinden oldukça farklıdır..."

Üç arkadaşın tahminleri Şekil 1'de verilmiştir. 


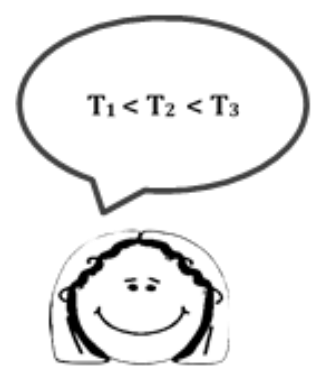

Ayşe (...)

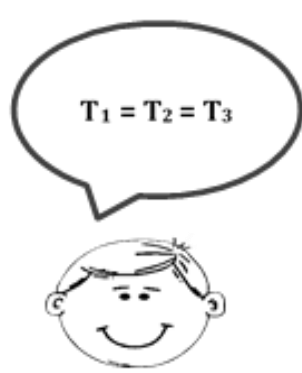

Mehmet (...)

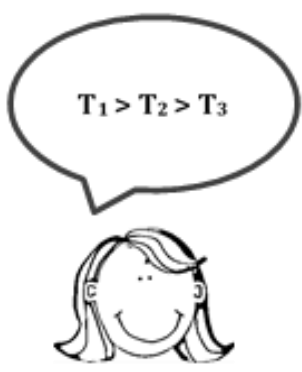

Umay (...)

Şekil 1. Üç arkadaşın tahminleri

Yarı açık uçlu deney süreci:

“Gelen bu farklı yanıtlar sonucunda öğretmen bu deneyi öğrencilerden yapmalarını ister. Öğrenciler, gerekli malzemeleri temin ederek düzeneği kurup, süreleri kronometre ile ölçmeye başlarlar. Dairesel hareket yapan kütlenin bir tam turunun çok kısa olduğunu ve kronometre ile ölçmenin çok zor olacağını fark eden Mehmet arkadaşlarına, kütlenin 10 tam turu için geçen süreleri ölçme ve buradan periyot ölçümüne geçme önerisinde bulunur. Bu fikrin güzel olacağını düşünen Umay, tek bir ölçümle doğru sonuçlar elde edemeyeceklerini belirterek, her yarıçap mesafesi için aynı işlemlerin birden fazla örneğin 5'er kez tekrarlanmasının gerekliliğini vurgular. Ayșe de Mehmet ve Umay arkadaşlarının fikirlerine katılır ve birlikte verileri almaya koyulurlar."

$\checkmark$ Önce; $10 \mathrm{~cm}$ yarıçaplı bir dairenin 10 tam turu için geçen süreleri 2,40 s; 2,42 s; 2,38 s; $2,43 \mathrm{~s} ; 2,47 \mathrm{~s}$

$\checkmark$ Sonra; $30 \mathrm{~cm}$ yarıçaplı bir dairenin 10 tam turu için geçen süreleri 2,85 s; 2,82 s; 2,96 s; $2,79 \mathrm{~s} ; 2,93 \mathrm{~s}$ ve

$\checkmark$ Daha sonra; $50 \mathrm{~cm}$ yarıçaplı bir dairenin 10 tam turu için geçen süreleri 3,11 s; 3,14 s; 3,17 s; 3,14 s; 3,20 s olarak kâğıda not alırlar.

Hazır olarak verilen şekiller Şekil 2'de verilmiştir.
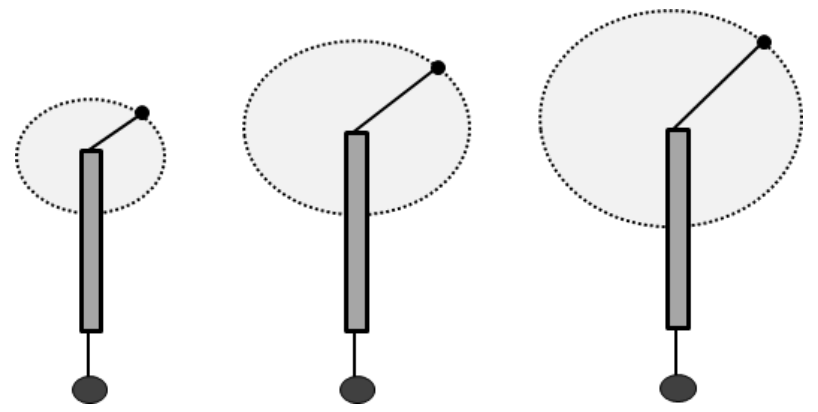

Şekil 2. Hazır olarak verilen şekiller 


\section{Verilerin Analizi}

Etkinlik kâğıdında yer alan verilerin değerlendirilmesi için kullanılan 17 değerlendirme kriteri, fen alan uzmanı ve bilim uzmanı araştırmacılar tarafından çeşitli kodlamalar oluşturularak hazırlanan havuzdan oluşturulmuştur. Bu değerlendirme kriterlerinin analizi için ise likert tipi yeterli, kısmen yeterli ve yetersiz olmak üzere 3 boyut belirlenmiştir. İki araştırmacının değerlendirme kriterleri ve boyutları karşılaştırılarak geçerlilik sağlanmıştır. Araştırmada nitel verileri analiz etme yöntemi olarak betimsel analiz kullanılmıştır. Yıldırım ve Şimşek (2006) betimsel analizi; verilerin önceden belirlenen temalara göre özetlenip yorumlanması olarak tanımlarken; var olan boyutlardan yola çıkarak oluşturulan tematik çerçeveye göre veriler yerleştirilmektedir. Burada bulgular tanımlanarak gerekli yerlerde ise doğrudan alıntılar sunularak yorumlanmaya gidilmektedir. Nitekim söz konusu araştırmada da bilimsel doğruluk içeren tam ifadeler yeterli, kısmen bilimsel doğruluk içeren ifadeler (doğru sayısı yanlış sayısından fazla ise) kısmen yeterli ve hatalı ifadelerin fazla olması (yanlış sayısı doğru sayısından fazla ise) ve boş yanıtlar yetersiz olarak kodlanmıştır.

Bir araştırmanın bilimsel olarak doğru değerlendirilmesi için başka araştırmacılar tarafından da incelenmesi gerekmektedir (Yıldırım ve Şimşek, 2006; Yıldırım, 2010). Bu nedenle çalışmada iki araştırmacının; [Görüş Birliği/(Görüş Ayrılı̆̆g + Görüş Birliği) x 100] formülü ile uyuşum yüzdesine (Miles ve Huberman, 1994) bakılmış ve bu değer \%90 olarak hesaplanmıştır.

\section{BULGULAR}

Öğretmen adaylarının grafik oluşturma süreci öncesinde problem senaryosunu analiz etme becerilerine ilişkin bulgular analiz edilerek sunulmuştur. Öğretmen adaylarının tahminde bulunma becerisinin değerlendirilmesi Tablo 1'de verilmiştir.

Tablo 1

Tahminde bulunma becerisinin değerlendirilmesi

\begin{tabular}{lccc}
\hline Değerlendirme Kriteri & Yeterli & $\begin{array}{c}\text { Kismen } \\
\text { yeterli }\end{array}$ & Yetersiz \\
\hline $\begin{array}{l}\text { Senaryoya dayalı bir tahminde bulunma ve } \\
\text { sebebini açlklayabilme }\end{array}$ & 34 & 42 & 11 \\
\hline
\end{tabular}

Tablo 1 incelendiğinde öğretmen adaylarının; senaryoya dayalı bir tahminde bulunma ve sebebini açıklayabilme becerisi için kısmen yeterli $(\mathrm{f}=42)$ oldukları görülmektedir. Öğretmen adaylarının şekil üzerine veri kaydetme becerisinin değerlendirilmesi Tablo 2'de verilmiştir. 
Tablo 2

Şekil üzerine veri kaydetme becerisinin değerlendirilmesi

\begin{tabular}{lccc}
\hline Değerlendirme Kriteri & Yeterli & $\begin{array}{c}\text { Kismen } \\
\text { yeterli }\end{array}$ & Yetersiz \\
\hline $\begin{array}{l}\text { Senaryo içerisinde geçen değişkenlere ait } \\
\text { verileri, hazır olarak verilen şekiller üzerinde } \\
\text { gösterebilme }\end{array}$ & 20 & 32 & 35 \\
\hline
\end{tabular}

Tablo 2 incelendiğinde öğretmen adaylarının; senaryo içerisinde geçen değişkenlere ait verileri, hazır olarak verilen şekiller üzerinde gösterebilme becerisi için yetersiz ( $\mathrm{f}=35$ ) oldukları görülmektedir. Öğretmen adaylarının hipotez ve değişkenleri belirleme becerisinin değerlendirilmesi Tablo 3'te verilmiştir.

Tablo 3

Hipotez ve değişkenleri belirleme becerisinin değerlendirilmesi

\begin{tabular}{lccc}
\hline Değerlendirme Kriterleri & Yeterli & $\begin{array}{c}\text { Kismen } \\
\text { yeterli }\end{array}$ & Yetersiz \\
\hline $\begin{array}{l}\text { Senaryoya ait uygun bir hipotez belirleyebilme } \\
\text { Bağımsız değişkeni ifade edebilme }\end{array}$ & 58 & 24 & 5 \\
$\begin{array}{l}\text { Bağımlı değişkeni ifade edebilme } \\
\text { Kontrol edilen (sabit) değişkenleri ifade }\end{array}$ & 38 & 20 & 34 \\
edebilme & - & 75 & 12 \\
\hline
\end{tabular}

Tablo 3 incelendiğinde öğretmen adaylarının; senaryoya ait uygun bir hipotez belirleyebilme becerisi için yeterli ( $\mathrm{f}=58$ ), bağımsız değişkeni ifade edebilme becerisi için yeterli ( $f=38$ ), bağımlı değişkeni ifade edebilme becerisi için yeterli ( $f=37$ ) ve kontrol edilen (sabit) değişkenleri ifade edebilme becerisi için kısmen yeterli $(f=75)$ oldukları görülmektedir. Öğretmen adaylarının tablo oluşturabilme becerisinin değerlendirilmesi Tablo 4'te verilmiştir. 
Tablo 4

Tablo oluşturabilme becerisinin değerlendirilmesi

Değerlendirme Kriterleri

Yeterli

Kismen
yeterli

Senaryoya dayanarak uygun bir tablo oluşturabilme

69

13

5

Senaryodaki verileri düzenleyerek tabloya

kaydedebilme

4

46

37

Tablo için değişkenlere ait birim ve sembolleri

doğru ifade edebilme

Tablo 4 incelendiğinde öğretmen adaylarının; senaryoya dayanarak uygun bir tablo oluşturabilme becerisi için yeterli $(\mathrm{f}=69)$, senaryodaki verileri düzenleyerek tabloya kaydedebilme becerisi için kısmen yeterli $(\mathrm{f}=46)$ ve tablo için değişkenlere ait birim ve sembolleri doğru ifade edebilme becerisi için kısmen yeterli (f=39) oldukları görülmektedir. Öğretmen adayları tarafından oluşturulan örnek bir tablo, Şekil 3'te verilmiştir.

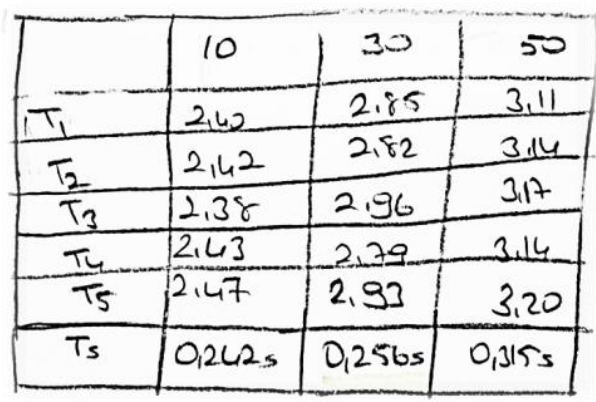

Şekil 3. Örnek tablo

Şekil 3 incelendiğinde, öğretmen adayının (Ö63k) 10 tam tur için geçen süreler için de periyot (T) sembolünü kullandığı fakat birim olarak saniyeyi (s) ifade etmediği ve yarıçap değişkenini tablo üzerinde sembol (r) ve birimle ( $\mathrm{cm}$ veya $\mathrm{m}$ ) ifade etmediği görülmektedir. Öğretmen adaylarının grafik çizme becerisinin değerlendirilmesi Tablo 5 'te verilmiştir. 
Tablo 5

Grafik çizme becerisinin değerlendirilmesi

Değerlendirme Kriterleri

Yeterli

Kısmen
yeterli

Tablodaki verilere dayanarak uygun bir grafik

oluşturabilme

84

Değişkenleri eksenler üzerinde doğru

konumlandırabilme

40

4

43

Grafik için değişkenlere ait birim ve sembolleri doğru

ifade edebilme

8

56

Verileri eksenlere orantılı bir şekilde yerleştirebilme

71

14

2

Tablodaki verileri milimetrik kâğıt üzerinde doğru

yerleştirebilme

7

73

7

Belirlenen noktanın etrafında küçük bir çember

çizerek veriye ait noktayı gösterebilme

14

66

7

Belirlenen noktaları kapsayan uygun bir doğru/eğri çizebilme

Başlangıçtaki tahmin ile gözlem sonuçları arasındaki benzerlik ve farklılıkları açıklayabilme

Tablo 5 incelendiğinde öğretmen adaylarının; tablodaki verilere dayanarak uygun bir grafik oluşturabilme becerisi için yeterli ( $\mathrm{f}=84)$, değişkenleri eksenler üzerinde doğru konumlandırabilme becerisi için yetersiz ( $\mathrm{f}=43$ ), grafik için değişkenlere ait birim ve sembolleri doğru ifade edebilme becerisi için kısmen yeterli $(\mathrm{f}=56)$, verileri eksenlere orantılı bir şekilde yerleştirebilme becerisi için yeterli $(\mathrm{f}=71)$, tablodaki verileri milimetrik kağıt üzerinde doğru yerleştirebilme becerisi için kısmen yeterli (f=73), belirlenen noktanın etrafında küçük bir çember çizerek veriye ait noktayı gösterebilme becerisi için kısmen yeterli ( $\mathrm{f}=66$ ), belirlenen noktaları kapsayan uygun bir doğru/eğri çizebilme becerisi için yeterli $(\mathrm{f}=79)$ ve başlangıçtaki tahmin ile gözlem sonuçları arasındaki benzerlik ve farklılıkları açıklayabilme becerisi için kısmen yeterli (f=35) oldukları görülmektedir.

Öğretmen adayları tarafından oluşturulan örnek bir grafik, Şekil 4'te verilmiştir. 


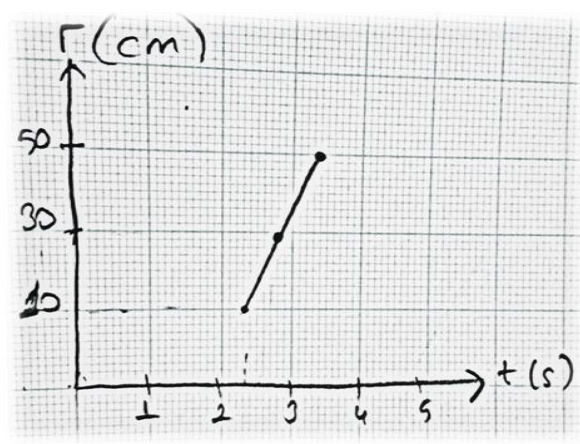

Şekil 4. Örnek grafik

Şekil 3 incelendiğinde, öğretmen adayının (Ö40k) çizmiş olduğu grafiğe göre bağımlı (periyot-T) ve bağımsız (yarıçap-r) değişkenleri doğru eksenlere yerleştiremediği ve periyot T(s) yerine her bir ölçüm için elde edilen süre değeri için kullanılan $t(s)$ 'ye çiziminde yer verdiği görülmektedir.

\section{SONUÇ, TARTIŞMA VE ÖNERILLER}

Bilimsel süreç becerilerinden verileri kaydetme, verileri kullanma ve model oluşturma, verileri yorumlama basamaklarını kapsayan tablo ve grafik oluşturma ile ilgili olarak Fen Bilgisi öğretmen adaylarının, verilen bir problem senaryosuna ilişkin bilimsel süreç becerilerinin tablo ve grafik oluşturabilme düzeylerinin yetersiz, kısmen yeterli ve yeterli olduğu noktaların bulunduğu tespit edilmiştir. Bir senaryodan elde edilen verilerin özümsenip belirlenmesi ve bu verilerin grafiğe dönüştürülme süreci bilimsel süreç becerileri ile oldukça ilişkili olarak görülmektedir. Mevcut bir durumdan verileri belirleyip çıkarabilme, bu verilerden grafik oluşturabilme ve grafiği yorumlayabilme becerisi, bilim okuryazarlığı bakımından oldukça önemli bir durum olarak ifade edilebilir. Nitekim Yeh ve McTigue'e göre (2009), birçok alanda karar verebilecek bireylerin yetiştirilebilmesi için tablo ve grafik okuma gibi görsel okuryazarlığın özellikle erken yaşlarda öğretilmesi gerektiği vurgulanmaktadır. Söz konusu bu durumu bireyde gerçekleștirebilecek en önemli kişi ise özellikle Fen Bilgisi öğretmenleri olarak görülmektedir.

Araştırmadan elde edilen sonuçlar incelendiğinde, Fen Bilgisi öğretmen adaylarının senaryoya ait uygun bir hipotez belirleyebilme, bağımlı ve bağımsız değişkenleri ifade edebilme konularında yeterli düzeyde bulunmalarına karşın, senaryoya dayalı tahminde bulunma ve sebebini açılayabilme, kontrol edilen (sabit) değişkenleri ifade edebilme konularında kısmen yeterli olmaları; senaryo içerisinde geçen değişkenlere ait verileri hazır olarak verilen şekiller üzerinde gösterebilme, değişkenleri eksenler üzerinde doğru konumlandırabilme konularında ise yetersiz olmaları dikkat çekici durumlar olarak karşımıza çıkmaktadır. Bu noktada özellikle değişken belirlemede Fen Bilgisi öğretmen adaylarının biraz daha deneyime ihtiyaç duydukları görülmektedir. 
Yine Fen Bilgisi öğretmen adaylarının senaryodan bir tablo ve tablodan verilere dayanarak uygun bir grafik oluşturabildikleri belirlenirken; senaryo içerisinde geçen değişkenlere ait verileri hazır olarak verilen şekiller üzerinde gösterebilme konusunda ise yetersiz olmaları senaryodan verileri çıkarabilme ve yorumlayabilme ile ilgili olarak öğretmen adaylarında henüz bu becerinin tam olarak gelişmediğini gösterir niteliktedir. Kozcu Çakır ve Sarıkaya'nın (2018) yapmış oldukları çalışmada da, öğretmen adaylarının bütünleştirilmiş süreç becerilerine ilişkin; hipotez kurma ve yorumlama, değişkenleri belirleme, grafiği okuma ve yorumlama, deney tasarlama ve sonuçlarını yorumlama, deney verilerini kaydetme gibi boyutlarda iyi düzeyde beceriye sahip oldukları belirlenirken; bağımlı, bağımsız ve kontrol edilen değişkenlerin tanımlanmasında ve belirlenmesinde, bilimsel süreç becerilerini tanımlamada ve kavramada ise sıkıntı yaşadıkları görülmüştür. Nitekim bilimsel süreç becerileri ile ilgili yapılan bir diğer araştırma incelendiğinde, öğrencilerin verileri ve grafiği yorumlamada eksiklikleri olduğu görülmektedir (Bowen ve Roth, 2005). Bu doğrultuda Talaslığlu ve Şahin (2018), bireyin algılarında farklılık oluşturulması adına, uluslararası sınavlarda yer verilen grafik okuma becerisine yeterli önemin verilmesi ve desteklenmesi gerektiğini vurgulamışlardır.

Abdi (2014) tarafından yapılan çalışmada, araştırmaya dayalı öğrenme yönteminin öğrencilerin fen bilimleri dersindeki akademik başarılarına etkisi olduğu belirlenmiştir. Kaptan ve Korkmaz’a (1999) göre bilimsel süreç becerisi; gözlemlenebilir bilgileri organize etmekten daha fazlasını ve bu becerileri kazanarak günlük yaşamda kullanmayı ve fen bilimlerine karşı daha olumlu tutum sahibi olmayı geliştirmektedir. Ünaldı (2012) tarafından yapılan araştırma sonucunda, bilimsel süreç becerilerini temel alan fen eğitimi uygulamasının öğrencilerin fen ve teknoloji dersine ilişkin tutumlarını ve bilimsel süreç becerilerini olumlu şekilde değiştirmiş olduğu belirlenmiştir. Öyle ki Meador (2003), bir bilim insanı gibi düşünmenin ve tartışmanın bilimsel süreç becerileri için gerekli olduğu üzerinde durmuştur. Tüm bu literatür ve sonuçlardan yola çlkarak özellikle uluslararası düzeyde öğrencilerimizin rekabet edebilir ve bu düzeylerde becerilerini geliştirebilir bir noktaya gelebilmeleri adına öğretim sürecindeki var olan bu eksiklikler ile daha etkin olarak çalışılması gerektiği düşünülmektedir. Problem senaryoları ile ilişkilendirilmiş ve tablo, grafik, şekil oluşturma gibi basamakları içeren deneysel aktivitelerin, öğrencilerin bilimsel süreç becerilerini geliştirmesi ve sorgulamaya dayalı öğrenmenin daha etkin olarak yapılandırılabilmesi adına önemli olduğu düşünülmektedir.

$\mathrm{Bu}$ bağlamda, bu tür uygulamaların farklı konu, içerik ve kazanımlara uyarlanarak öğretmen adaylarının benzer durumlar ile daha fazla karşılaştırılması gerektiği düşünülmektedir. 


\section{Kaynaklar}

Abdi, A. (2014). The effect of inquiry-based learning method on students' academic achievement in science course. Universal Journal of Educational Research, 2(1), 37-41.

Anagün, Ş. S. ve Yaşar, Ş. (2009). İlköğretim beşinci sınıf fen ve teknoloji dersinde bilimsel süreç becerilerinin geliştirilmesi. İlköğretim Online, 8(3), 843-865.

Aydoğdu, B. (2009). Fen ve teknoloji dersinde kullanılan farklı deney tekniklerinin öğrencilerin bilimsel süreç becerilerine, bilimin doğasına yönelik görüşlerine, laboratuvara yönelik tutumlarına ve öğrenme yaklaşımlarına etkileri. Yayınlanmamış Doktora Tezi, Dokuz Eylül Üniversitesi Eğitim Bilimleri Enstitüsü, İzmir.

Başdaş, E. (2007). İlköğretim fen eğitiminde, basit malzemelerle yapılan fen aktivitelerinin bilimsel süreç becerilerine, akademik başarıya ve motivasyona etkisi. Yayınlanmamış Yüksek Lisans Tezi, Celal Bayar Üniversitesi, Fen Bilimleri Enstitüsü, Manisa.

Bowen, G. M. ve Roth, W. M. (2005). Data and graph interpretation practices among preservice science teachers. Journal of Research in Science Teaching, 42(10), 1063-1088.

Büyüköztürk, Ş., Kılıç Çakmak, E., Akgün, Ö. E., Karadeniz, Ş. ve Demirel, F. (2008). Bilimsel araştırma yöntemleri. Ankara: Pegem Akademi.

Demir, S. (2014). Bilimsel tartışma ve araştırmaya dayalı tasarlanan laboratuvar programının, Fen Bilgisi öğretmen adaylarının bilimsel yaratıcılıklarına etkisi. Yayınlanmamış Doktora Tezi, Marmara Üniversitesi Eğitim Bilimleri Enstitüsü, İstanbul.

Ewers, T. G. (2001). Teacher-directed versus learning cycles methods: Effects on science process skills mastery and teacher efficacy among elementary education students. Unpublished Doctoral Dissertation, University of Idaho, Moscow.

Kaptan, F. ve Korkmaz, H. (1999). Illköğretimde etkili öğretme ve öğrenme öğretmen el kitabı. İlköğretimde Fen Bilgisi Öğretimi, Modül 7.

Karamustafaoğlu, O. ve Yaman, S. (2006). Fen eğitiminde özel öğretim yöntemleri I-II. Ankara: Anı.

Kemiksiz, C. (2016). 6. sınıf fen bilimleri dersinde senaryo temelli öğrenme yönteminin akademik başarı tutum ve kalıcılığa etkisi. Yayınlanmamış Yüksek Lisans Tezi, Abant İzzet Baysal Üniversitesi, Eğitim Bilimleri Enstitüsü, Eğitim Bilimleri Anabilim Dalı, Eğitim Programları ve Öğretimi Bilim Dalı, Bolu.

Kozcu Çakır, N. ve Sarıkaya, M. (2018). Fen Bilgisi öğretmen adaylarının bilimsel süreç becerilerinin değerlendirilmesi. Turkish Studies, 13(4), 859-884.

Küçüközer, H. (2017). Fizik öğretiminde problem tabanlı öğrenme ve problem çözme stratejisi. A. İ. Şen ve A. R. Akdeniz (Eds.), Fizik öğretimi, kuramsal bilgiler ve örnek etkinlik uygulamaları içinde (ss. 251-283), 1. Baskl, Ankara: Pegem Akademi.

Meador, K. S. (2003). Thinking creatively about science suggestions for primary teachers. Gifted Child Today, 26(25), 25-29.

Medrano, J. (2012). The effect of cognitively guided instruction on primary students' math achievement, problem solving abilities and teacher questioning. Unpublished Doctoral Dissertation, Arizona State University, USA.

Miles, M. B. ve Huberman, A. M. (1994). Qualitative data analysis. (2nd ed.), Thousand Oaks: Sage.

Ongowo, R. O. ve Indoshi, F. C. (2013). Science process skills in the Kenya certificate of secondary education biology practical examinations. Creative Education, 4(11), 713-717. 
Sezgin Selçuk, G. (2015). A problem-based learning scenario that can be used in science teacher education. Asia-Pacific Forum on Science Learning and Teaching, 16(2), 1-26.

Şahin, F. ve Benzer, E. (2012). Dört soru stratejisiyle geliştirilen proje uygulamalarının bilimsel süreç becerilerine etkisi. Necatibey Eğitim Fakültesi Elektronik Fen ve Matematik Eğitimi Dergisi (EFMED), 6(1), 306-337.

Şensoy, Ö. ve Yıldırım, H. İ. (2017). Araştırma soruşturma tabanlı öğrenme yaklaşımının yaratıcı düşünme ve bilimsel süreç becerilerine etkisi. Cumhuriyet International Journal of Education (CIJE), 6(1), 34-46.

Talaslığlu, S. S. ve Şahin, F. (2018). Ortaokul 7. sınıf öğrencilerinin grafik okuryazarlığı etkinlikleri ile karar verme becerileri ve kavram öğrenmeleri arasındaki ilişkinin incelenmesi guage. Journal of Human Sciences, 15(1), 62-76.

Tan, M. ve Temiz, B. K. (2003). Fen öğretiminde bilimsel süreç becerilerinin yeri ve önemi. Pamukkale Üniversitesi Eğitim Fakültesi Dergisi, 1(13), 89-101.

Ünaldı, Ö. (2012). Bilimsel süreç becerilerine dayalı fen eğitiminin öğrencilerin fen ve teknoloji dersine ilişkin tutumlarına ve bilimsel süreç becerilerine etkisi. Yayınlanmamış Yüksek Lisans Tezi, Ankara Üniversitesi, Eğitim Bilimleri Enstitüsü, Ölçme ve Değerlendirme Anabilim Dalı, Ankara.

Werner, R. J. (2007). Inquiry-based learning at Minnesota's University of St. Thomas. International Journal of Learning, 14(1), 51-56.

Yeh, Y. F. Y. ve McTigue, E. M. (2009). The frequency, variation, and function of graphical representations. School Science and Mathematics, 109(8), 435-449.

Yıldırım, A. ve Şimşek, H. (2006). Sosyal bilimlerde nitel araştırma yöntemleri. Ankara: Seçkin.

Ylldırım, K. (2010). Nitel araștırmalarda niteliği artırma. İlköğretim Online, 9(1), 79-92.

Yıldırım, M. ve Türker Altan, S. (2017). Araştırma ve sorgulamaya dayalı öğrenme yaklaşımının ilkokul öğrencilerinin bilimsel süreç becerilerine etkisi. Mustafa Kemal Üniversitesi Sosyal Bilimler Enstitüsü Dergisi, 14(38), 71-89. 
"Bilimsel Süreç Becerileri ve Grafik Oluşturabilme Düzeylerinin İncelenmesi: Fen Bilgisi Öğretmen Adayları Örneği” başlıklı çalışmanın yazım sürecinde bilimsel, etik ve alıntı kurallarına uyulmuş; toplanan veriler üzerinde herhangi bir tahrifat yapılmamış, karşılaşılacak tüm etik ihlallerde "Sakarya University Journal of Education Dergisi ve Editörünün" hiçbir sorumluluğunun olmadığı, tüm sorumluluğun yazarlara ait olduğu ve çalışmanın herhangi başka bir akademik yayın ortamına değerlendirme için gönderilmemiş olduğu bu çalışmanın yazarları tarafından taahhüt edilmiştir. 